\title{
WEAR QUANTIFICATION OF BASAL CUTTING KNIVES IN SUGARCANE HARVESTING
}

\author{
Carla S. S. Paixão ${ }^{1 *}$, Murilo A. Voltarelli², Luan P. de Oliveira ${ }^{3}$, Leonardo Bernache ${ }^{3}$, \\ Rouverson P. da Silva ${ }^{3}$
}

${ }^{1 *}$ Corresponding author. Universidade de Sorocaba/ Sorocaba - SP, Brasil.

E-mail: carla.paixao@prof.uniso.br | ORCID ID: https://orcid.org/0000-0001-7280-1219

\section{KEYWORDS}

basal cutting, control charts, mechanized harvesting, quality indicator, statistical process control.

\begin{abstract}
The mechanized harvesting of sugarcane has increased exponentially in recent years because of the gradual prohibition of burning on the cane fields in mechanizable and nonmechanizable areas. This study aimed to evaluate the wear of the basal cutting knives in two different mechanized sugarcane harvesters, through statistical process control. The experiment was conducted in Cravinhos, São Paulo, in an agricultural area, on July 25, 26, and 27, 2016. Two harvesters with different basal cutting mechanisms were evaluated: harvester A-Model BE1035e (conventional type knife), and harvester B-Model A8800 (racket type knife). The experimental design was completely randomized with two treatments. The wear was quantified by measuring the thickness increase and width losses of each knife, and it was evaluated for each harvester every 2 hours, during 3 days of operation. Data were evaluated using descriptive statistics and statistical process control. The harvester B model (racket knife) presented lower variability in the cutting width and stability in the cutting width of the knives. The harvester A model (conventional knife) presented greater wear in the width, but less variability in the thickness of the cutting wire.
\end{abstract}

\section{INTRODUCTION}

Mechanized sugarcane harvesting has become the main method of crop residue disposal in sugarcane producing regions of Brazil, as the burning of sugarcane fields has become prohibited,. The cut made at the base of the sugarcane stalk has a direct influence on the sugarcane yield loss, power demand of the harvester, damage to the ratoon, and contamination of the raw material. According to Cassia et al. (2014), the wear of the basal cutting knives of sugarcane harvesters is associated with the indexes of damage and strikes to the rump knobs, which occur due to the wear of the cutting wire that becomes thicker and increases the incidence of damage and strikes to the ratoons, thereby potentially damaging the regrowth of the sugarcane field.

The statistical process control (SPC) is widely used in agricultural studies to monitor, evaluate, and improve production performance, as it takes into account the production of conforming and nonconforming variables in certain lines or production processes. Therefore, some authors have used SPC to verify changes in quality indicators. In these studies, control charts are normally used to identify nonrandom causes or special causes due to process instability (Cassia et al., 2013; Chioderoli et al.,
2012; Noronha et al., 2011; Silva et al., 2011; Suguisawa et al., 2007; Toledo et al., 2008).

Current studies that determine wear by comparing different models of basal cutting knives are scarce, and the existing ones do not take into account the assumption that basal cutting knives of different types influence the quality of the harvest, thus, based on the assumption that the wear between different models of knives, behave in different ways, the objective of this study was to evaluate, using SCP, the wear of two different models of knives used in basal cutting during the mechanized harvest of sugarcane.

\section{MATERIAL AND METHODS}

The experiment was carried out in an agricultural area in the city of Cravinhos, SP, Brazil, between $21^{\circ} 24^{\prime} 09^{\prime \prime} \mathrm{S}$ and $47^{\circ} 49^{\prime} 10^{\prime \prime} \mathrm{W}$, with an average altitude of $604 \mathrm{~m}$. The Köppen classification of climate is Cwa. Soil of the experimental area was classified as dystrophic RED LATOSOL, with a smooth, undulating relief (Embrapa, 2013).

The cultivated variety of sugarcane in both treatments (Harvester A e B) was SP80-1816, in the 3rd cutting season, planted in rows spaced $1.50 \mathrm{~m}$ apart, with a mean productivity of $75.9 \mathrm{t} \mathrm{ha} \mathrm{h}^{-1}$. This variety is

${ }^{2}$ Universidade Federal de São Carlos/ Buri - SP, Brasil.

${ }^{3}$ Universidade Estadual Paulista "Julio de Mesquita Filho"/ Jaboticabal - SP, Brasil.

Received in: 10-11-2018

Accepted in: 6-3-2019 
characterized by the sprouting of ratoons, fast vegetative development, and upright stance, and is an excellent model for mechanized cutting.

Two harvester models were used. Harvester A: Model BE 1035E, equipped with an ACGO Power 9.8 L engine of $350 \mathrm{cv}(257.42 \mathrm{~kW})$, equipped with a wheeled treadmill of $1.94 \mathrm{~m}$ width, working at an average velocity of $4.0 \mathrm{~km} \mathrm{~h}^{-1}$, and a primary extractor rotation of $1300 \mathrm{rpm}$ during the morning and $1000 \mathrm{rpm}$ during the afternoon. Harvester A had a base cutting mechanism composed of rotors and discs, with 6 knives on each disc, totaling 12 rectangular-shaped knives, known as conventional knives (Fig. 1a) with 4 cutting faces.

Harvester B was the Model A8800 multi-row, Cummis C9 engine, $358 \mathrm{cv}(263 \mathrm{~kW})$, with hydrostatic transmission, equipped with a wheeled running machine of $1.88 \mathrm{~m}$ width, working approximately $5.5 \mathrm{~km} \mathrm{~h}^{-1}$, with primary extractor rotation fixed throughout the day at $800 \mathrm{rpm}$. Harvester B had 4 knives in each basal cutting mechanism, with a total of 8 knives in a circular shape, known as "racket" knives of the Repar-parts brand (Fig. 1b).

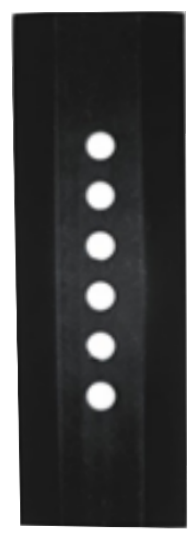

(a)

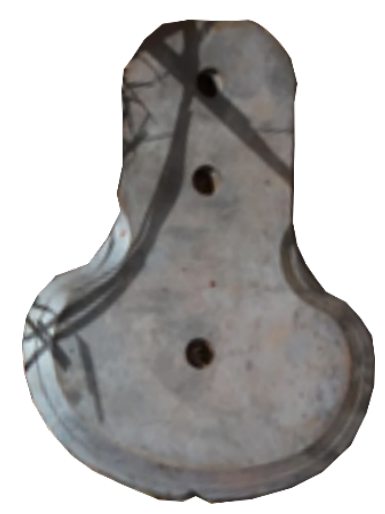

(b)
FIGURE 1. Conventional and "racket" knife models used in the basal cutting system of the harvesters A and B (Valtra BE 1035E and CASE IH A8800 MULTI-ROW). (a) Conventional knife. (b) Racket knife.

New sets of knives were installed on the harvesters on the first day of the experiment. The sets of 12 and 8 knives of the conventional and racket models, respectively, were weighed using a precision balance with $0.01 \mathrm{~g}$ of resolution, and the mean weights of the knives were used to represent each harvester (conventional model: $0.80 \mathrm{~kg}$ each; racket model: $0.84 \mathrm{~kg}$ each). The knives were inverted according to power plant criteria (each 8 hours).
The experimental design was a completely randomized design using the two harvesters (Harvester A conventional knife model and Harvester B - racket knife model) as treatments. The quality indicators were evaluated every 2 hours of effective work during 3 days of operation. Harvester A had 180 samples (12 knives $\times 15$ harvesters) and harvester $B$ had 120 samples ( 8 knives $\times$ 15 harvesters). The quality indicators evaluated were the thickness of the cutting wire and the width of each knife, following the methodology of Voltarelli et al. (2015), using a pachometer. The width of the conventional knife was measured at the shortest length of the cutting face, while the width of the circular knife was measured from the center to the cutting wire, measuring the radius. Minitab ${ }^{\circledR}$ software was used to calculate the general mean, standard deviation, coefficient of variation, asymmetry coefficient, and kurtosis. The Ryan-Joiner test was used to verify the normality of the data.

Control charts were used for individual and moving range values. A process under control, (i.e., stable) shows only random variation within the upper and lower control limits in the individual value charts or moving range charts. However, a process that has points outside the upper and lower control limits shows variation due to special causes that are unmarked or external and nonrandom, in both control charts (Cassia et al., 2013; Zerbato et al., 2013).

The control charts of individual values and moving ranges present the means of the quality indicators at each evaluation point, and present the mean as a central line through the points and the upper and lower control limits (UCL and LCL), which are calculated based on the standard deviation of each variable (Montgomery, 2009).

\section{RESULTS AND DISCUSSION}

For the basal cutting mechanism of harvester A, the width and thickness of the left side knives showed a nonnormal distribution according to the Ryan-Joiner test (Table 1). Conversely, the width and thickness of the right side knives showed a normal distribution.

The width of the knives on the left side of the basal cutting mechanism presented a positive asymmetry coefficient and negative kurtosis, representing a behavior of a sharp, right-skewed distribution, respectively, and presented the lowest coefficients of variation and standard deviations, in relation to the cutting thickness.

TABLE 1. Descriptive statistics for the quality indicators of the basal cutting mechanism of sugarcane harvester A.

\begin{tabular}{|c|c|c|c|c|c|c|c|}
\hline \multirow{2}{*}{ Quality indicator } & \multicolumn{7}{|c|}{ Left side } \\
\hline & $\overline{\mathrm{X}}$ & $\sigma$ & $\mathrm{CV}$ & $\mathrm{Cs}$ & $\mathrm{Ck}$ & $\mathrm{RJ}$ & p-Valor \\
\hline Width (cm) & 7.89 & 0.66 & 8.34 & 0.13 & -1.31 & 0.974 & $<0.01^{\mathrm{A}}$ \\
\hline \multirow[t]{2}{*}{ Thickness (mm) } & 0.38 & 0.06 & 17.88 & 0.05 & 1.04 & 0.982 & $0.01^{\mathbf{A}}$ \\
\hline & \multicolumn{7}{|c|}{ Right side } \\
\hline Width (cm) & 7.96 & 0.61 & 7.75 & -0.12 & -1.01 & 0.988 & $0.08^{\mathrm{N}}$ \\
\hline Thickness (mm) & 0.39 & 0.06 & 15.21 & -0.04 & -0.65 & 0.991 & $>0.10^{\mathrm{N}}$ \\
\hline
\end{tabular}

$\overline{\mathrm{X}}$ - General mean; $\sigma$ - Standard deviation; CV (\%) - Coefficient of variation; Cs - Coefficient of asymmetry; Ck - Coefficient of kurtosis; $\mathrm{RJ}$ - Ryan-Joiner normality test; $\mathrm{p}$-value $(>0.01)-\mathrm{N}$ normal distribution; A - nonnormal distribution. 
For the harvester B model, the thickness of the cutting wire on both sides of the basal cutting mechanism presented a normal distribution (Table 2). However, the distribution of the cutting width for the left and right sides of the basal cut was nonsignificant. Also, the coefficient of variation for the cutting width of the right side of the basal cut mechanism was low, according to Pimentel-Gomes \& Garcia (2002).

The negative asymmetry coefficient of the width on the left side indicated that there was a higher concentration of points above the mean (i.e., the mean was less than its median), as discussed by Voltarelli et al. (2015).

TABLE 2. Descriptive statistics for the quality indicators of the basal cutting mechanism of sugarcane harvester B.

\begin{tabular}{|c|c|c|c|c|c|c|c|}
\hline \multirow{2}{*}{ Quality indicator } & \multicolumn{7}{|c|}{ Left side } \\
\hline & $\overline{\mathrm{X}}$ & $\Sigma$ & $\mathrm{CV}$ & $\mathrm{Cs}$ & $\mathrm{Ck}$ & $\mathrm{RJ}$ & p-Valor \\
\hline Width (cm) & 6.53 & 0.73 & 11.26 & -0.92 & 0.48 & 0.949 & $<0.001^{\mathrm{A}}$ \\
\hline Thickness (mm) & 0.30 & 0.07 & 23.88 & 0.03 & -0.99 & 0.985 & $>0.10^{\mathrm{N}}$ \\
\hline & \multicolumn{7}{|c|}{ Right side } \\
\hline Width (cm) & 6.41 & 0.58 & 9.13 & 0.50 & -1.05 & 0.965 & $<0.01^{\mathrm{A}}$ \\
\hline Thickness (mm) & 0.31 & 0.08 & 27.79 & 0.14 & -0.89 & 0.985 & $>0.10^{\mathrm{N}}$ \\
\hline
\end{tabular}

$\overline{\mathrm{X}}$ - General mean; $\sigma$ - Standard deviation; CV (\%) - Coefficient of variation; Cs - Coefficient of asymmetry;Ck - Coefficient of kurtosis; $\mathrm{RJ}$ - Ryan-Joiner Normality test; p-value ( $>0.01)$ - N normal distribution; A - nonnormal distribution.

The SPC showed that the width of the rectangular knives of the basal cutting mechanism on the left side of harvester A was stable during all hours of use, for both the control chart of individual and mobile rang values (Fig. 2), indicating a good quality of operation. The greatest variability occurred after 10 hours of use, which was confirmed by the moving range control chart, indicating lower quality during the mechanical harvesting of sugarcane in this time interval.

Voltarelli et al. (2017) evaluated damage and shake to the strikes caused by basal cutting knives with and without coating, and concluded that the harvesting operation has better quality when using coated knives. Their conclusions concur with this study, as coated knives were less susceptible to the wear of the cutting wire and caused less damage and shake to the ratoons. Overall, the conventional knives of harvester A presented better quality of harvesting, due to less wear of the wire.
The right side of the basal cutting mechanism showed instability during the 2 hours of use, and greater variability during the 20 hours of use (Fig. 2). There was a point that extrapolated the upper control limit, also observed in the moving range control chart, and the limits were far apart, which indicated poor operation quality. The knife width on both sides of the basal cutting mechanism decreased over time, which was a normal and expected response of this quality indicator, and showed there was no excessive breakage of knives or accelerated wear from contact with the soil. These results concur with those reported by Gray et al. (2009), who reported a decrease in the width and length of knives, and an increase in the thickness of the cutting wire as the basal cutting mechanism touched the soil and stalks during sugarcane harvesting, which was observed in this study.

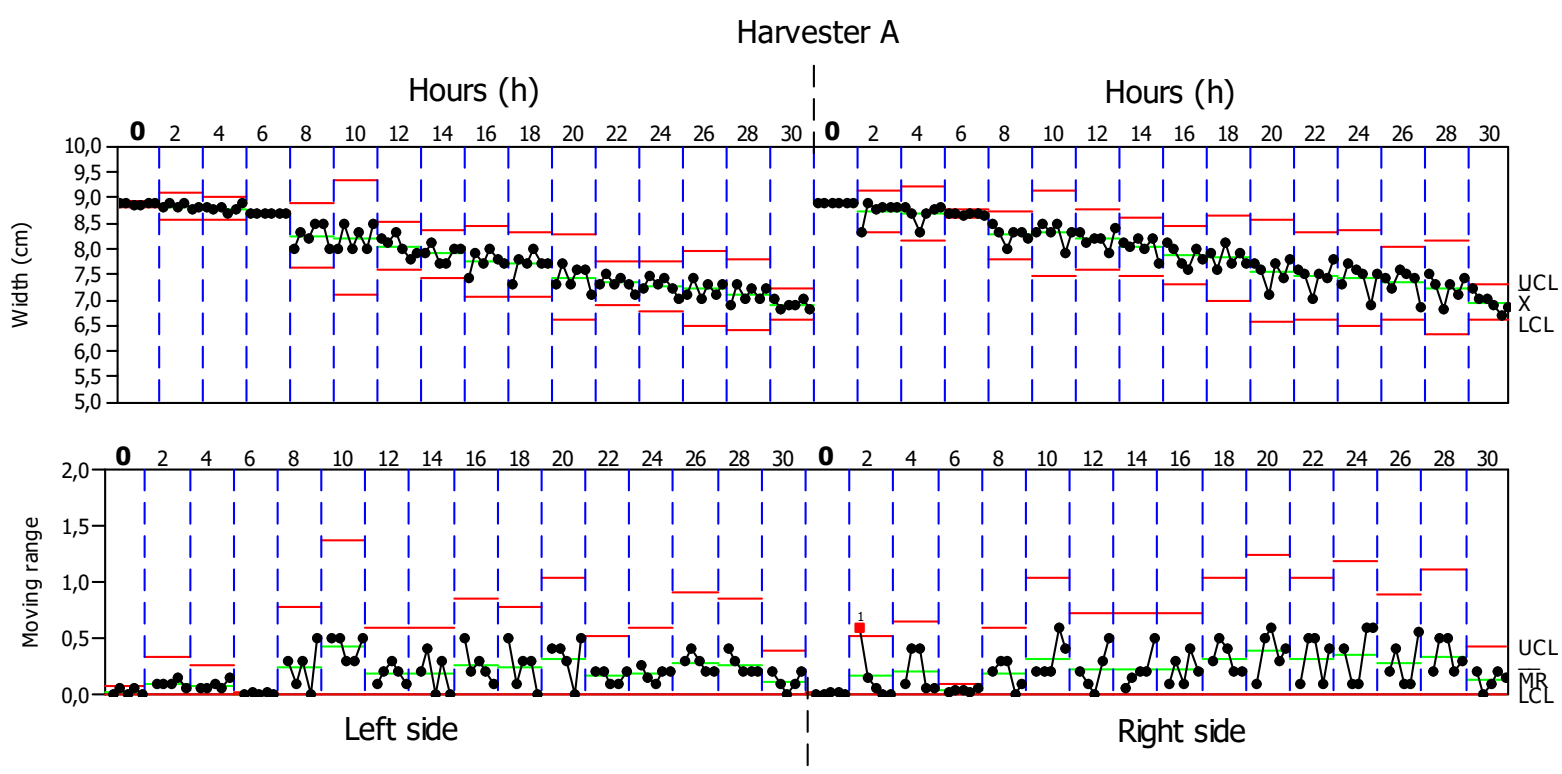

FIGURE 2. Individual and moving range control charts of the cutting width on the left and right sides of the basal cutting mechanism of Harvester A. a) Individual values control chart. (b) Moving range control chart. UCL: upper control limit. LCL: Lower control limit. $\overline{\mathrm{X}}$ : Mean. $\overline{\mathrm{M}} \mathrm{R}$ : Moving range. 
Harvester B showed stability in knife width on both sides, as all points were between the upper and lower control limits for individual and moving range charts (Fig. 3). The lower variability of the harvesting operation was verified to the right side of the base cutting mechanism comparing with the left side.

The cutting width of the circular knife (wear radius) on the left side of the basal cutting mechanism from 0 to 14 hours showed a natural wear pattern. However, between 16 to 30 hours of use, the cutting width of the knife oscillated between larger and smaller values (individual values chart), which was due to the high number of knife changes after breakages or natural wear from contact with the ratoons and friction with the ground.
The high breakage rate of the knives might have been caused by the contact with the soil profile at the time of harvesting, as the knife was submitted to forces for which it was not designed, resulting in the rupture, shearing, or wear of the knives. The contact of the cutting knives with the soil profile can be caused by errors in the cutting height control mechanism or by inexperienced harvest operators. Reis et al. (2015) evaluated the quality of the basal cut in different soil management regimes and attributed the high loss of basal cutting knives to the soil. Therefore, it was assumed that the operator was unable to efficiently control the height of the cut or respond to changes in the soil profile.

Harvester B
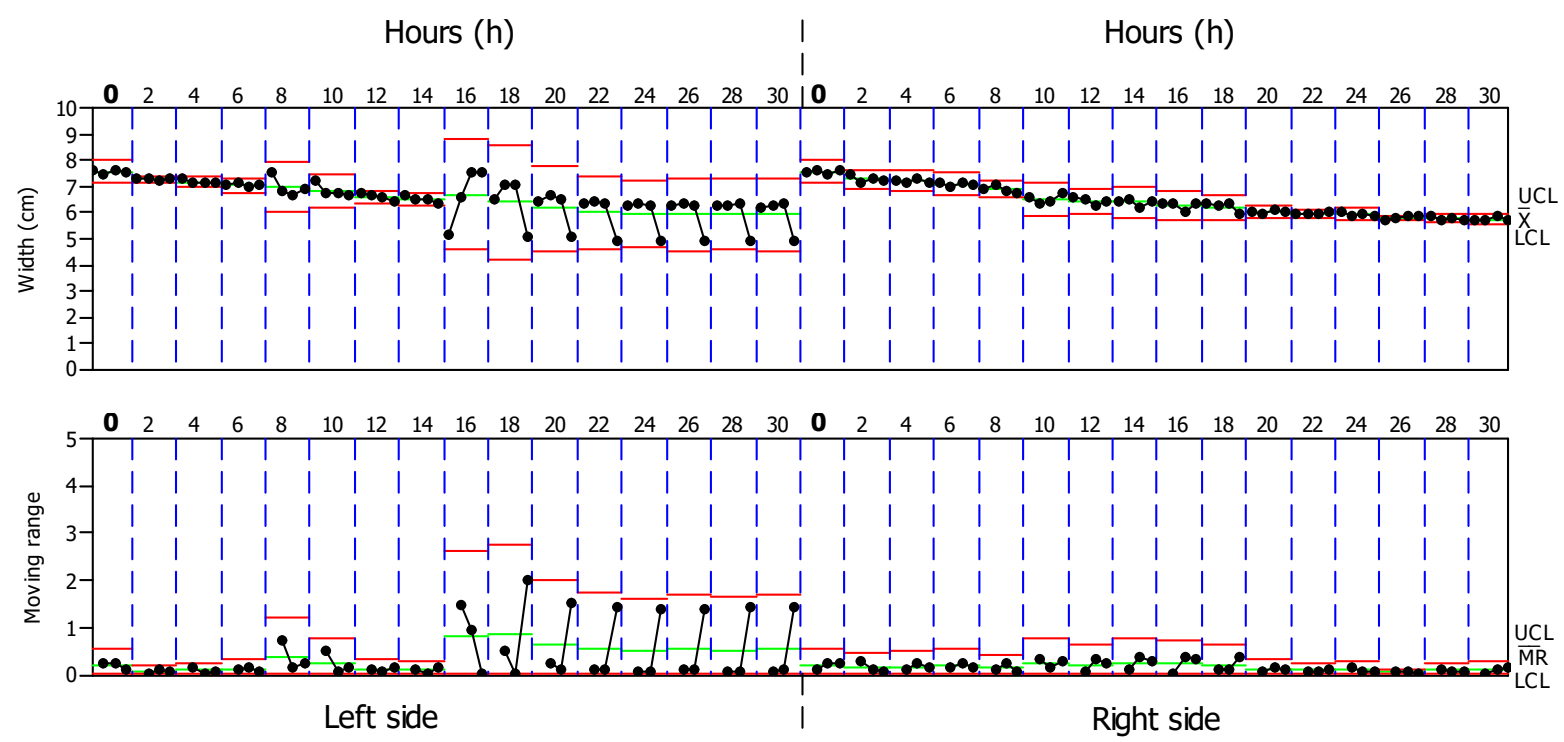

FIGURE 3. Individual and moving range control charts for the cutting width on the left and right sides of the basal cutting mechanism of Harvester B. a) Individual values control chart. (b) Moving range control chart. UCL: upper control limit. LCL: Lower control limit. $\overline{\mathrm{X}}$ : Mean. $\overline{\mathrm{M}} \mathrm{R}$ : Moving range.

The cutting knife thickness of harvester A showed process instability on the right side of the basal cutting mechanism at $6,8,10,22$, and 26 hours of use, with multiple points that exceed the upper and lower control limits (Fig. 4).

The thickness of the cutting wire during mechanized harvesting of sugarcane can be influenced by the contact with the ratoons, which is considered natural wear, and by contact with the soil. Depending on the amount of silica, the wear can be increased and reduce the lifespan of the knives. The thickness of the cutting wire of rectangular knives is responsible for the impact of cutting in the rows of ratoons. As the amount of time the knives were used increased, the thickness of the cutting wire gradually increased, until it reached a limit at which it did not cut efficiently. This was observed on both sides of the basal cutter mechanism of harvester A. 


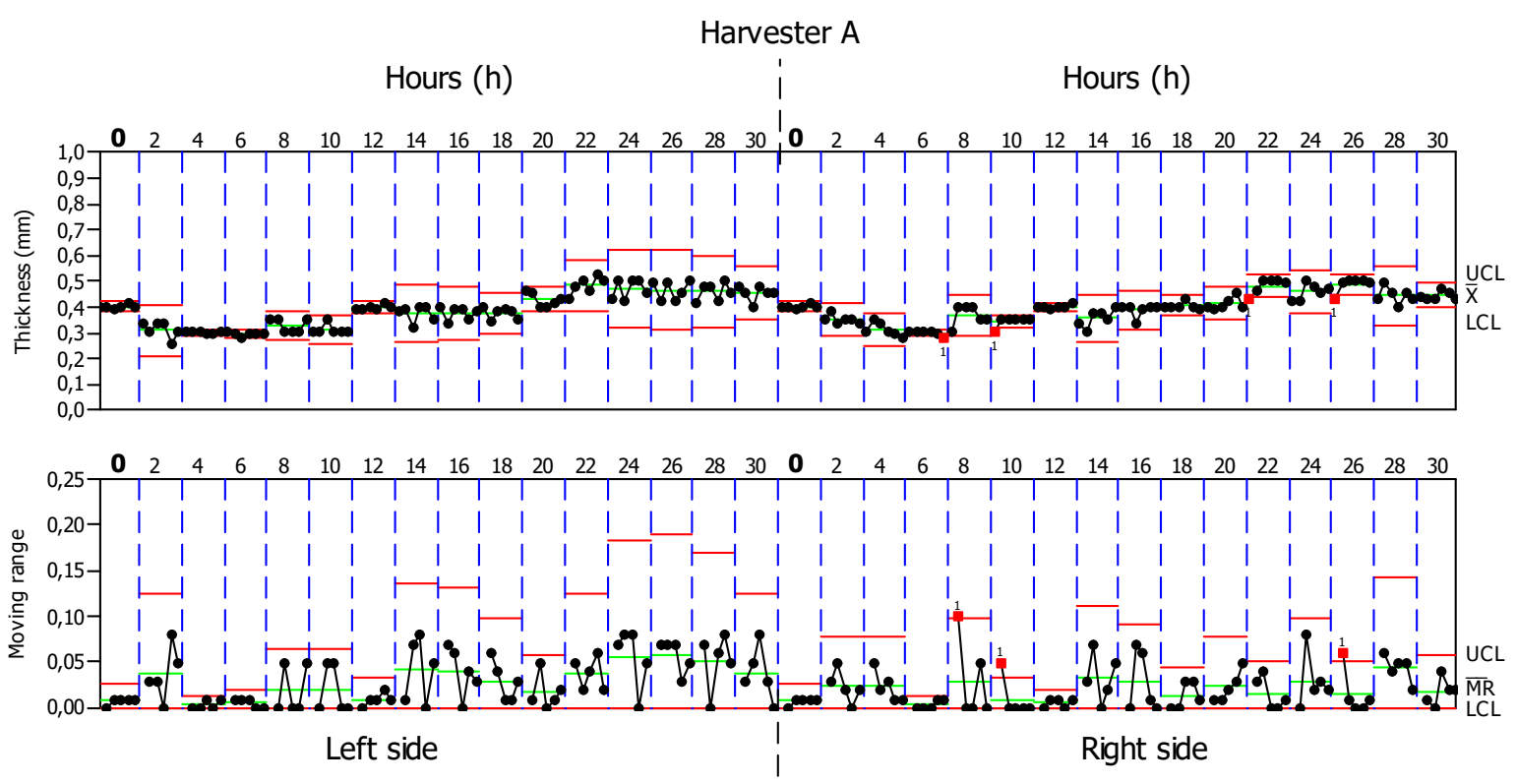

FIGURE 4. Individual values and moving range control charts for the thickness of the cutting wire on the left and right sides of the basal cutting mechanism of Harvester A. a) Individual values control chart. (b) Moving range control chart. UCL: upper control limit. LCL: Lower control limit. $\overline{\mathrm{X}}$ : Mean. $\overline{\mathrm{M}} \mathrm{R}$ : Moving range.

For harvester B, the cutting wire presented stability on both sides, at all times of use (Fig. 5), which demonstrated the quality of the operation. The greatest variation for the left and right sides occurred after 8 and 14 hours use, respectively.

The mean thickness of the cutting wire on the left side of harvester B did not increase over time. This was because the knives were replaced due breakage or natural wear. For example, the thickness of the cutting wire is smaller when a knife is used less, than when it has been replaced. Conversely, on the right side of the basal cutting mechanism, the change in knife width was not continuous compared with that in the left side, and this was reflected in the thickness of the cutting wire for the circular knives (racket knives), which showed similar behavior to the rectangular knives used in harvester $\mathrm{A}$.

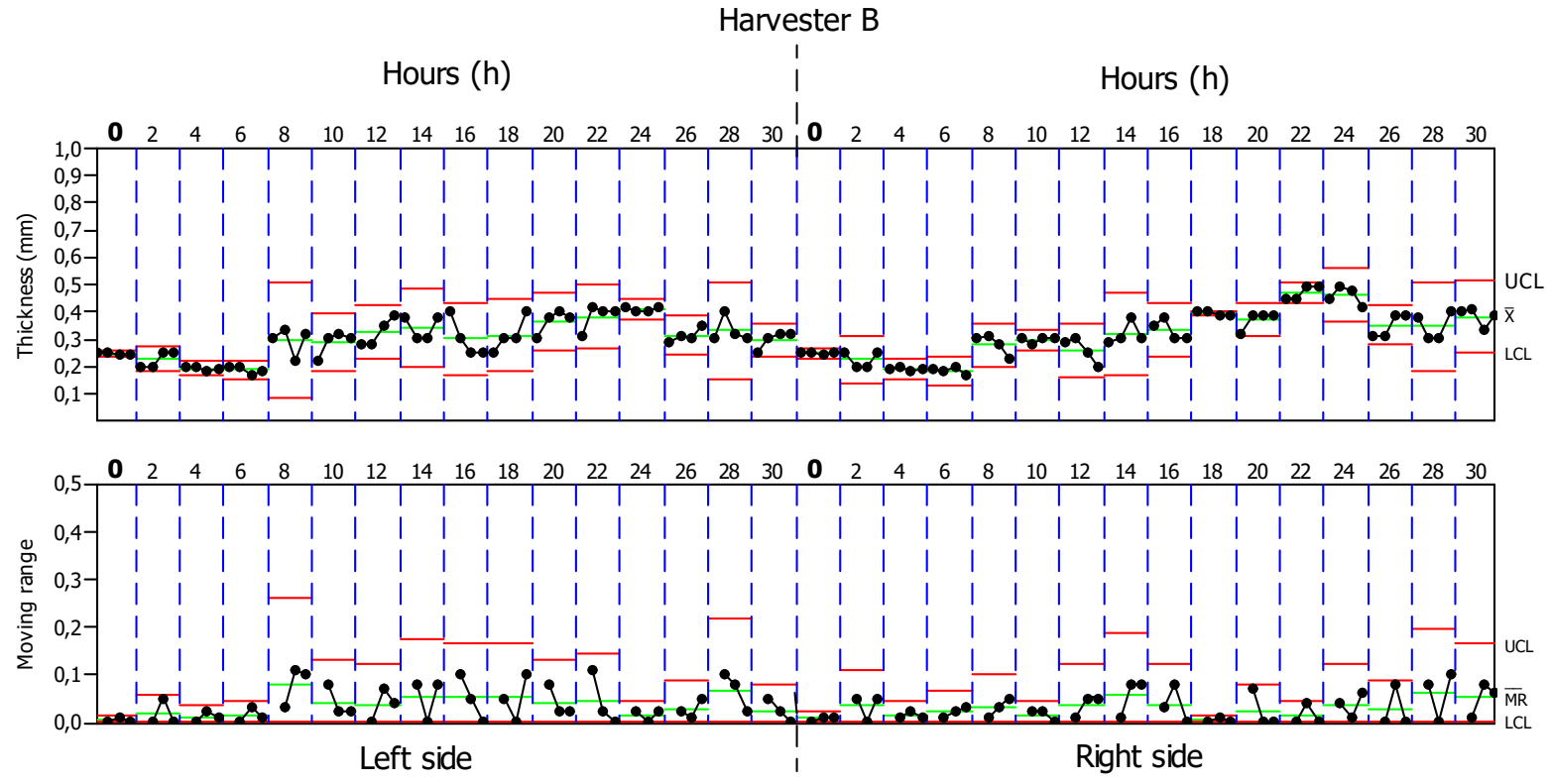

FIGURE 5. Individual values and moving range control charts of the thickness of the cutting wire on the left and right sides of the basal cutting mechanism of Harvester B. a) Individual values control chart. (b) Moving range control chart. UCL: upper control limit. LCL: Lower control limit. $\overline{\mathrm{X}}$ : Mean. $\overline{\mathrm{M}} \mathrm{R}$ : Moving range. 


\section{CONCLUSIONS}

Harvester B equipped with the racket-type knives presented lower cutting width variability and stability in knife width. Harvester B presented stability in the thickness of the cutting wire on both sides, and at all times presented better quality of operation. Harvester A equipped with conventional knives presented greater wear in knife width and less variability in the thickness of the cutting wire.

\section{REFERENCES}

Cassia MT, Silva RP, Chioderolli CA, Noronha RHF, Santos EP (2013) Quality of mechanized coffee harvesting in circular planting system. Ciencia Rural 43(1):28-34.

Cassia MT, Silva RP, Paixão CCS, Bertonha RS, Cavichioli FA (2014) Desgaste das facas do corte basal na qualidade da colheita mecanizada de cana-de-açúcar [Basal cutting knives wear in the quality of mechanized sugarcane harvesting]. Ciência Rural 44(6):987-993.

Chioderoli CA, Silva RP, Noronha RHF, Cassia MT, Santos EP (2012) Perdas de grãos e distribuição de palha na colheita mecanizada de soja [Losses of grains and distribution of straw in soybean mechanized harvesting]. Bragantia 71(1):112-121.

Embrapa (2013) Sistema brasileiro de classificação de solos [Brasilian soil classification]. Embrapa-SPI.

Gray GR, Magalhães PSG, Braunbeck OA (2009) Suspensão pantográfica para o corte de base de cana-deaçúcar [Pantographic suspension for sugar cane base cuter]. Ciência Rural 39(3):766-771.

Montgomery DC (2009) Introdução ao controle estatístico da qualidade [Introduction to statistical quality control]. Rio de Janeiro, LTC, 4 ed.

Noronha RHF, Silva RP, Chioderoli CA, Santos EP, Cassia MT (2011) Controle estatístico aplicado ao processo de colheita mecanizada diurna e noturna de canade-açúcar [Statistical control applied in the process of mechanical sugar cane harvest in the diurnal and nocturnal periods]. Bragantia 70(4):931-938.
Pimentel-Gomes F, Garcia CH (2002) Estatística aplicada a experimentos agronômicos e florestais: exposição com exemplos e orientações para uso de aplicativos [Statistics applied to agricultural and forest experiments: exposure with examples and guidelines for application use]. Piracicaba, FEALQ.

Reis GN, Voltarelli MA, Silva RP, Toledo A, Lopes A (2015) Qualidade do corte basal na colheita mecanizada de cana-de-açúcar em dois tipos de manejo do solo [Quality harvesting in the basement cut of sugarcane soil management systems]. Comunicata Scientiae 6(2):143-153.

Silva RP, Ferreira IC, Cassia MT (2011) Perdas na colheita mecanizada de algodão [Losses in cotton mechanized hasvest]. Scientia Agropecuária 2(1):7-11.

Suguisawa JM, Franco FN, Silva SSS, Filho AP (2007) Qualidade de aplicação de herbicida em lavoura de trigo [Quality of application of herbicide in wheat crop]. Engenharia Agrícola 27:41-47.

Toledo A, Tabile RA, Silva RP, Furlani CEA, Magalhães SC, Costa BO (2008) Caracterização das perdas e distribuição de cobertura vegetal em colheita mecanizada de soja [Characterization of losses and crop residue cover distribution in soybean mechanized harvest]. Engenharia Agrícola 28(4):710-719.

Voltarelli MA, Silva RP, Cassia MT, Ortiz DF, Torres LS (2015) Qualidade do corte basal de cana-de-açúcar utilizando-se de três modelos de facas [Basal cut quality in sugarcane plants using three knife models]. Engenharia Agrícola 35(2):528-541.

Voltarelli MA, Silva RP, Cassia MT, Daloia JGM, Paixão CSS (2017) Qualidade do corte basal de cana-de-açúcar efetuado por facas de diferentes angulações e revestimentos [Quality of basal cutting in sugarcane using knives of diferente coating and angles]. Revista Ciência Agronômica 48(2):438-447.

Zerbato C, Cavichioli FA, Raveli MB, Marrafon M, Silva RP (2013) Controle estatístico de processo aplicado à colheita mecanizada de milho [Statistical process control applied to mechanized maize harvest with different cutting platforms]. Engenharia na Agricultura 21(3):261-270. 